Ogilvie describes experiments upon the depth of planting, and the effects of high and low temperatures, on lily bulbs. One cannot escape the conclusion, however, on considering the contents of the present volume, that it deals with less fundamental questions than previous issues.

\section{Leeds College of Technology}

ON the occasion of the distribution of prizes and certificates by Sir William Bragg on December 7, the principal of the Leeds College of Technology presented a report on the work of the last session, emphasizing the value to the local industries of the thoroughly up-to-date technical instruction given in the College to more than three thousand of their personnel. The total number of students was 3,862 , of whom 3,320 attended evening classes only and 375 attended part-time day and evening classes. Although education authorities are often inclined to disparage evening classes on the ground that after a hard day's work people cannot be expected to be fit for serious study, they are nevertheless a very valuable part of the country's educational resources. As the principal points out, they are, moreover, capable of exerting a definitely beneficial effect on character: "To attend evening classes regularly after the day's work, for several sessions, each of which includes an English winter, is an indication of grit and perseverance in addition to intellectual ability". It is noteworthy that 379 students were released by employers to attend part-time day classes, generally in addition to evening classes.

\section{Vocational Guidance}

A 'Vocational Guidance' pamphlet has been issued by the University College of the South-West of England, Exeter, for the use of parents and others. It gives a list of the various college courses with particulars of their duration and the fees payable for them, a list of vocations (other than teaching) for which the courses offer suitable preparation, and a list of other vocations. The attention of parents is directed to the fact that in some cases the course of study is of one year's duration only and entails no long or expensive training. Accompanying the pamphlet is a leaflet directing attention to the increased demand for scientific investigators both for routine and research duties, to the importance for entry into commerce or industry of good qualifications in modern languages and economics, and to a new course for a diploma in public administration. This diploma will, it is anticipated, be a valuable qualification for higher posts in the national and local government services.

\section{The Laxminarayan Technical Institute, Nagpur}

THE foundation stone of the Laxminarayan Technological Institute was laid by His Excellency Sir Hyde Clarendon Gowan, Chancellor of the Nagpur University, at Nagpur on December 8, 1937. The Chancellor paid great tribute to the untiring efforts of the present Vice-Chancellor, Sir Hari Singh Gour, in acquiring the present site for the Institute, which will be surrounded by charming scenery. The construction of the Laxminarayan Technological Institute and its workshop is the result of a princely bequest, now amounting to more than $£ 400,000$, made by the late Rao Bahadur D. Laxminarayan in 1930 to the University of Nagpur for the teaching of applied science and chemistry. The University has decided to begin with the creation of a department of applied chemistry for teaching and research work in this subject. Dr. R. S. Thakur, who had been deputed for the last two years by the University of Nagpur to visit England and the continent of Europe for practical training in applied chemistry, with special reference to oil technology, has now been appointed as the organizing officer. It is expected that the Institute will be in active operation about July of next year.

\section{Refrigeration Conference}

A Refrigeration Conference will be held in London on July 12, in the rooms of the Royal Society. This Conference, which is convened by the British Association of Refrigeration, will take place immediately following a meeting at the same centre of the Technical Commissions of the International Institute of Refrigeration, an organization with headquarters in Paris. The subjects provisionally set down for discussion at the Conference, which will be open to all technicians interested in refrigeration, are: influence of low temperatures on enzymes, vitamins, etc. ; limitations of 'gas storage'; air conditioning problems; an international unit of refrigeration; standard tables giving the properties of refrigerants. Further information can be obtained from the Hon. Secretary, British Association of Refrigeration, Empire House, St. Martin's-le-Grand, London, E.C.1.

\section{Mathematical Colloquium at St. Andrews.}

A Mathematrcal colloquium, similar to the very successful gatherings held in 1926, 1930 and 1934, will be held in St. Andrews on July 4-July 15, 1938, under the auspices of the Edinburgh Mathematical Society. Short courses of lectures will be given by prominent mathematicians, including Prof. E. T. Whittaker, Prof. G. D. Birkhoff, Dr. A. C. Aitken, on topics of pure and applied mathematics. On their way to the colloquium, members will have the opportunity of attending a meeting of the Royal Society of Edinburgh, celebrating the three hundredth anniversary of the birth of James Gregory, who held in succession the chairs of mathematics in the Universities of St. Andrews and Edinburgh. This meeting will be held in Edinburgh on July 4. Further particulars of membership of the colloquium can be obtained from the Hon. Secretary, Edinburgh Mathematical Society, 16 Chambers Street, Edinburgh 1.

\section{The Night Sky in February}

FULL moon occurs on February 14 at $17 \cdot 2^{\mathrm{h}}$ and new moon on March 2 at $5 \cdot 7^{\text {h }}$ U.T. No occultation of stars brighter than magnitude $5 \frac{1}{2}$ occurs this month. 